\title{
KOMUNIKASI PERSUASIF DALAM DAKWAH BIL HIKMAH: UPAYA PEMBENTUKAN KARAKTER ANAK TUNA LARAS DI MADRASAH INKLUSI
}

\author{
Nursaptini, Arif Widodo \\ PGSD, FKIP, Universitas Mataram \\ nursaptini@unram.ac.id
}

\begin{abstract}
Abstrak
Anak tuna laras identik dengan perilaku yang buruk. Stigma anak tuna laras sebagi anak nakal telah melekat. Anak tuna laras memiliki masalah yang serius dengan karakter. Permasalahan semacam ini juga terjadi di salah satu madrasah inklusi di Lombok Barat. Penelitian ini bertujuan untuk mengetahui pengaruh metode pembentukan karakter terhadap anak tuna laras di madrasah inklusi. Penelitian in ididesain dalam bentuk penelitian kualitatif dengan pendekatan studi kasus. Subjek dalam penelitian ini terdiri dari lima anak tuna laras. Permasalahan utama dalam penelitian ini adalah bagaimana pengaruh penggunaan metode dakwah bil hikmah terhadap perubahan karakter anak tuna laras? Berdasarkan hasil penelitian dapat disimpukan bahwa pembentukan karakter anak tuna laras di madrasah inklusi dengan menggunakan pendekatan komunikasi persuasif dari metode dakwah bil hikmah telah berhasil. Guru memperlakukan anak tuna laras dengan kasih sayang, mau mendengar keluh kesah dan melakukan komunikasi persuasif. Penggunaan pendekatan ini dapat merubah perilaku anak tuna laras, emosi menjadi lebih stabil, hubungan sosial membaik dan partisipasi belajar meningkat.
\end{abstract}

Kata Kunci: komunikasi persuasif, dakwah bil hikmah, tuna laras, pembentukan karakter

\begin{abstract}
Children with emotionally handicapped identic with bad behavior. The stigma as a naughty children has lingered. Children with emotionally handicapped have serious character problems. This kind of problem also occurs in one of inclusion madrasas in West Lombok. This study aims to determine the effect of character building methods on children with emotionally handicapped in inclusion madrasah. This research was designed in qualitative research with a case study approach. The subjects in this study consist of five children with emotionally handicapped. The main problem in this research is how is the effect of using da'wah bil hikmah method on changes in children with emotionally handicapped character. Based on results of the study, it can be concluded that character building on children with emotionally handicapped in inclusion madrasah using persuasive communication approach da'wah bil hikmah method has been successful. The teachers treat the children with emotionally handicapped with love, willing to listen their complaints and makes persuasive communication. The use of this approach can change children with emotionally handicapped behaviour, their emotions become more stable, improve in social relations and increase in learning participation.

Keywords: persuasive communication, da'wah bil hikmah, children with emotionally handicapped, character building
\end{abstract}




\section{A. PENDAHULUAN}

Anak tuna laras sebagai bagian dari anak berkebutuhan khusus memiliki karakteristik yang unik. Setiap anak berkebutuhan khusus memiliki karakter masingmasing. ${ }^{1}$ Keunikan ini dapat terjadi pada anak yang memiliki jenis kebutuhan khusus yang sama. Maka dari itu dalam beberapa kajian literatur anak berkebutuhan khusus disebut juga sebagai anak luar biasa. ${ }^{2}$ Atas dasar keunikan yang dimiliki oleh anak berkebutuhan khusus maka tiap-tiap anak berkebutuhan khusus membutuhkan layanan yang berbeda sesuai dengan kekhususannya. ${ }^{3}$ Hal ini juga berlaku bagi anak tuna laras. Pada umumnya karakter anak tuna laras adalah tempramen, sulit diatur dan cenderung melakukan tindakan ekstrim. Tindakannya tidak hanya membahayakan dirinya sendiri tetapi juga orang lain di sekitarnya. Tindakan kekerasan anak tuna laras dapat diwujudkan dalam berbagai bentuk tindakan verbal dan non verbal. ${ }^{4}$

Anak tuna laras sebagai anak berkebutuhan khusus dapat dikategorikan memiliki perilaku sosial yang menyimpang dari anak pada umumnya. ${ }^{5}$ Perilaku sosial dan emosionalnya cenderung tidak terkontrol. Anak tuna laras juga memiliki hubungan yang buruk dengan teman sebaya. Implikasinya adalah anak tuna laras sering mendapat penolakan dari masyarakat maupun lingkungan pendidikan. ${ }^{6} \mathrm{Hal}$ ini tidak terlepas dari adanya ganguan perilaku yang dialami oleh anak tuna laras. Terdapat anggapan bahwa menerima anak tuna laras dalam lingkungan pendidikan dapat membahayakan keselamatan peserta didik yang lain. Pada umumnya pihak sekolah akan mendapatkan protes keras dari orang tua siswa yang anaknya yang normal jika menerima anak tuna laras di sekolah. Pihak sekolah dalam hal ini tidak dapat berbuat banyak. Akibatnya adalah sekalipun sekolah telah berlabel sekolah inklusi tidak semua anak berkebutuhan

1 Kaisa Vuorinen, Anne Erikivi, and Lotta Uusitalo-Malmivaara, 'A Character Strength Intervention in 11 Inclusive Finnish Classrooms to Promote Social Participation of Students with Special Educational Needs', Journal of Research in Special Educational Needs, 19.1, 2019, hlm. 45-57 <https://doi.org/10.1111/1471-3802.12423>.

2 Oki Dermawan, 'Strategi Pembelajaran Bagi Anak Berkebutuhan Khusus Di SLB', Psympathic : Jurnal Ilmiah Psikologi, 6.2, 2018, hlm. 886-97 <https://doi.org/10.15-575/psy.v6i2.2206>.

${ }^{3}$ Khairun Nisa, Sambira Mambela, and Lutfi Isni Badiah, Karakteristik Dan Kebutuhan Pembelajaran Anak Berkebutuhan Khusus Dan Anak Berbakat', Abadimas Buana, 2.1, 2018, hlm. 33-40.

${ }^{4}$ Luxvina Nurhansari, Identifikasi Perilaku Anak Tunalaras ( Anak Agresif) Di Sekolah Inklusi Siswa Kelas I SD N Bangunrejo 2 Yogyakarta, Jurnal Pendidikan Guru Sekolah Dasar, 29.7, 2018, hlm. 2.884-2.895.

${ }^{5}$ Nandiyah Abdullah, 'Mengenal Anak Berkebutuhan Khusus', Magistra, XXV.86, 2013, hlm. $1-10$.

${ }^{6}$ Aini Mahabbati, Pendidikan Inklusif Untuk Anak Dengan Gangguan Emosi Dan Perilaku $\begin{array}{lllll}\text { (Tunalaras), Jurnal } \quad \text { Pendidikan } & \text { Khusus, } & 7.2, & \text { 2010, } & \text { hlm.52-63 }\end{array}$ <https://doi.org/https://doi.org/10.21831/jpk.v7i2.778>. 
khusus dapat diterima. Salah satu anak berkebutuhan khusus yang masih sering mengalami diskriminasi adalah anak tuna laras. Akibatnya adalah banyak ditemukan anak tuna laras yang belum tertampung pada sekolah formal.

Seiring dengan keterbukaan akses terhadap pendidikan inklusif, anak tuna laras telah mendapatkan perhatian khusus. Telah banyak disediakan sekolah inklusi yang bersedia menerima anak tuna laras sebagai peserta didik. Lembaga pendidikan yang berkecimpung pada pendidikan inklusif telah berbenah diri. Salah satu penyebabnya adalah dukungan dari pemerintah terkait dengan pendidikan inklusi semakin nyata. Bahkan pemerintah telan mengeluarkan peraturan terbaru tentang penyediaan akomodasi yang layak bagi anak berkebutuhan khusus. Tidak ada alasan lagi bagi sekolah untuk tidak menerima anak berkebutuhan khusus, apapun itu jenisnya. Misi utama dalam pendidikan inklusi adalah pendidikan untuk semua. Tidak boleh ada diskriminasi dalam bidang pendidikan. Setiap anak bangsa berhak untuk mendapatkan pendidikan yang layak sesuai dengan jenis kebutuhannya. Perhatian yang serius dari pemerintah telah membuahkan hasil. Menurut berbagai penelitian diskriminasi pendidikan sudah jarang terdengar lagi. ${ }^{7}$ Termasuk dalam hal ini diskriminasi terhadap anak tuna laras. Namun demikian dengan diterimanya anak tuna laras dalam lngkungan pendidikan formal bukan berarti permasalahan telah selesai. Stigma buruk terhadap anak tuna laras masih melekat. Salah satu penyebab labeling buruk terhadap anak tuna laras adalah kurangnya pemahaman orang tua siswa dan guru terhadap hakikat anak tuna laras. ${ }^{8}$ Sosialisasi dan edukasi terhadap orang tua siswa masih kurang optimal. Akibatnya orang tua siswa sering mendapatkan informasi yang salah. Tidak hanya orang tua siswa, para guru juga masih sering mendapatkan pemahaman yang salah terhadap anak tuna laras. Bahkan sering dijumpai guru yang masih kesulitan dalam mengidentifikasi, melakukan assessment maupun program pembelajaran individual bagi anak berkebutuhan khusus. Masih banyak ditemukan guru di sekolah inklusi yang belum memiliki kemampuan khusus dalam menangani anak tuna laras. ${ }^{9}$

7 Ana Rafikayati dan Muhammad Nurrohman Jauhari, Keterlibatan Orangtua Dalam Penanganan Anak Berkebutuhan Khusus, Belantika Pendidikan, 2.1, 2018, hlm.28-36.

${ }^{8}$ Endhita Januar Bihastuti, Penerapan Healing Environment Pada Perancangan Sekolah Dasar Luar Biasa Bagian Tunalaras, ARSITEKTURA, 15.2, 2017, hlm. 447-54 <https://doi.org/10.20961/arst.v15i2.12596>.

${ }^{9}$ Ibnu Syamsi, Pelaksanaan Evaluasi Asesmen Akademik Siswa Tunalaras Di Slb-E Prayuwana, Jpk: Jurnal Pendidikan Khusus, 12.1, 2017, hlm.31-42 <https://doi.org/10.21831/jpk.v12i1.12837>. 
Stigma buruk terhadap anak tuna laras tidak terlepas dari perilaku tidak baik yang ditunjukkan. Anak tuna laras selain mengalami hambatan dalam perilaku juga mengalami hambatan dalam hubungan sosial dan pengendalian emosi. ${ }^{10}$ Secara kondisi anak tuna laras secara terus menerus selalu melakukan penyimpangan perilaku sehingga berpengaruh juga terhadap kemampuan akademik meskipun telah berkali-kali dilakukan treatmen. ${ }^{11}$ Hal ini berkaitan erat dengan karakter. Permasalahannya adalah mendidik karakter anak tuna laras tidaklah mudah. Dibutuhkan teknik khusus untuk mendidik karakter anak tuna laras. Hal ini dikarenakan karakteristik anak tuna laras sangat berbeda dengan anak yang normal. Anak yang memiliki gangguan sosial emosional dan perilaku membutuhkan penanganan khusus. Kesalahan dalam melakukan peanganan dapat berakibat buruk pada perilaku kesehariannya. Jika telah terbiasa akan menjadi karakter buruk yang sulit dikendalikan. Meskipun demikian bukan berarti perilaku anak tuna laras tidak dapat dirubah. Anak tuna laras dapat dibimbing agar dapat melakukan perubahan perilaku asalkan menggunakan cara yang tepat. ${ }^{12}$ Hal ini dikarenakan pada dasarnya setiap anak memiliki hati nurani yang akan menuntun ke jalan kebenaran.

Terdapat beberapa penelitian terdahulu yang membahas tentang fenomena pendidikan karakter bagi anak tuna laras. Salah satu diantaranya adalah penelitian tentang penggunaan metode permainan tradisional. ${ }^{13}$ Penelitian tersebut mendesain model permainan tradisional dan dikombinasikan dengan terapi neurosains. Hasil penelitiannya menunjukan bahwa metode permainan tradisional berbasis neurosains efektif dalam memperbaiki disfungsi sistem syaraf. Melalui perbaikan sistem syaraf tersebut respon psikologis berupa penyimpangan perilaku dan gangguan kepribadian anak tuna laras dapat terkontrol. Terapi perilaku yang mengandung unsur gerak juga telah dilakukan, salah satunya dengan memanfaatkan seni musik dan seni tari. Hasil

${ }^{10}$ Aini Mahabati, Pola Perilaku Bermasalah Dan Rancangan Intervensi Pada Anak Tunalaras Tipe Gangguan Perilaku (Conduct Disorder) Berdasarkan Fungsctional Behavior Assesment, Dinamika Pendidikan, 21.01, 2014, hlm. 1-21 <https://journal.uny.ac.id/index.php/dinamikapendidikan/article/view/2851>.

${ }^{11}$ Destri Wahyu Utami, Mohammad Anwar, and Hermawan Hermawan, Pengaruh Penggunaan Model Pembelajaran Assure Terhadap Peningkatan Prestasi Belajar IPA Anak Tunalaras Kelas IV Di SLB E Bhina Putera Surakarta Tahun Ajaran 2017/2018, JPI (Jurnal Pendidikan Inklusi), 2.1, 2018, hlm. 5-14 <https://doi.org/10.26740/inklusi.v2n1.p5-14>.

${ }^{12}$ Arif Rohman Hakim, Memuliakan Anak Berkebutuhan Khusus Melalui Pendidikan Jasmani Adaptif, Jurnal Ilmiah Penjas, 3.1, 2017, hlm. 17-27 <http://ejournal.utp.ac.id/index.php/JIP/article/view/539>.

13 Erik Burhaein, Aktivitas Permainan Tradisional Berbasis Neurosainslearning Sebagai Pendidikan Karakter Bagi Anak Tunalaras, Jurnal SPORTIF : Jurnal Penelitian Pembelajaran, 3.1, 2017, hlm. 55-68 <https://doi.org/10.29407/js_unpgri.v3i1.580>. 
penelitian membuktikan bahwa terapi menggunakan media musik dan tari dapat merubah tingkah laku dan emosi. ${ }^{14}$ Penelitian selanjutnya mengkaji tentang pengendalian diri anak tuna laras menggunakan modifikasi perilaku. Hasil penelitiannya menunjukkan bahwa teknik konseling behavioral yang dilakukan terbukti dapat meningkatkan kemampuan anak tuna laras dalam melakukan pengendalian diri. ${ }^{15}$

Selanjutnya penelitian yang mengkaji tentang perbedaan terapi murrotal menggunakan ayat suci Al_Quran dengan menggunakan musik. ${ }^{16}$ Hasil penelitiannya menunjukkan bahwa terapi murrotal (Ar-Rahman) lebih cepat menurunkan tingkat emosional anak tuna laras dibandingkan dengan terapi melalui musik. Lebih lanjut diungkapkan dalam penelitian tersebut bahwa penggunaan murrotal ayat suci dapat memperbaiki hubungan sosial anak tuna laras dengan teman sebaya. Penelitian tersebut sejalan dengan penelitian berikut yang mengkaji tentang penggunaan Al Quran sebagai media terapi. ${ }^{17}$ Simpulan akhir dari penelitian ini mengungkapkan bahwa melalui terapi Al-Quran anak tuna laras mengalami perubahan sikap dan perilaku menjadi lebih baik. Wujud perilakunya antara lain lebih tenang, dapat mengontrol diri, mengontrol emosi, dan dapat mengikuti kegiatan pembelajaran dengan baik. Penelitian selanjutnya berkaitan dengan pembentukan karakter anak tuna laras melalui internalisasi nilai-nilai religius. ${ }^{18}$ Nilai karakter tersebut diinternalisasikan melalui kegiatan pembelajaran dan pembiasaan kultur religius. Pembentukan karakter mengedepankan nilai-nilai kasih sayang dan kolaborasi dengan orang tua maupun lingkungan masyarakat. Penelitian selanjutnya mengkaji hal serupa, yaitu pembentukan karakter dengan pendekatan pendidikan akhlak. ${ }^{19}$ Hasil penelitian menunjukkan bahwa pendidikan akhlak pada anak tunalaras dilakukan dengan pengkondisian sopan santun, pembiasaan beribadah, dan

${ }^{14}$ Exwan A.V and others, Program "Lombok Rawit" Sebagai Sarana Terapi Bagi Anak Tunalaras, Pelita - Jurnal Penelitian Mahasiswa UNY, 9.02, 2014, hlm. 1-5.

${ }^{15}$ Aas Indriyati, Peningkatan Pengendalian Diri Pada Anak Tuna Laras Dengan Menggunakan Pendekatan Teknik Konseling Behavioral Di Smkn 3 Bandung, Jurnal Penelitian Pendidikan, 17.2, 2017, hlm. 105-9 〈https://ejournal.upi.edu/index.php/JER/article/view/8245>.

${ }^{16}$ Padila and others, Emosi Dan Hubungan Antar Sebaya Pada Anak Tunalaras Usia Sekolah Antara Terapi Musik Klasik (Mozart) Dan Murrotal (Surah Ar-Rahman), Jurnal Keperwatan Silampari, 3.2, 2020, hlm. 752-63 〈https://doi.org/10.31539/jks.v3i2.1276>.

${ }^{17}$ Ati Kusmawati, Cholichul Hadi, and M.G. Bagus Ani Putra, Terapi Al-Qur'an Pada Siswa Tunalaras, JSSH (Jurnal Sains Sosial Dan Humaniora, 2.1, 2018, hlm. 55-67 <https://doi.org/10.30595/jssh.v2i1.2199>.

${ }^{18}$ Difaul Husna, Internalisasi Nilai-Nilai Sosial Religius Bagi Anak Tunalaras Di SLB E Prayuwana Yogyakarta, Jurnal Tarbiyatuna, 11.1, 2020, hlm. 1-10 <https://doi.org/10.31603/tarbiyatuna.v11i1.3044>.

${ }^{19}$ La Ode Yarfin and Suyadi, Pendidikan Akhlak Pada Anak Tunalaras Di Sekolah Luar Biasa Prayuwana Yogyakarta, Jurnal Pendidikan Islam, 11.1 , 2020, hlm. 68-85. 
perilaku jujur. Lebih lanjut dijelaskan pada penelitian tersebut bahwa anak tuna laras memiliki kecenderungn meniru perilaku yang kurang baik. Maka dari itu anak tuna laras perlu dilakukan stimulasi akhlak terpuji melebihi pengaruh negatif dari lingkungan sekitarnya.

Beberapa penelitian terdahulu telah mengkaji upaya pembentukan karakter dan perubahan perilaku anak tuna laras dengan berbagai metode. Penelitian ini akan mengkaji tentang metode pembentukan karakter anak tuna laras pada salah satu madrasah inklusi di kabupaten Lombok Barat. Madrasah inklusi ini telah menerapkan pendidikan karakter dengan mengadopsi metode komunikasi persuasif sesuai dengan dakwah Rasulullah yang mengedepankan kelembutan. Tujuan penelitian ini adalah menganalisis bagaimana pengaruh metode komunikasi persuasif model dakwah Rasulullah dalam membentuk karakter anak tuna laras.

\section{B. METODE PENELITIAN}

Penelitian ini didesain dalam bentuk penelitian kualitatif. Pendekatan yang digunakan adalah studi kasus. Melalui pendekatan ini peneliti berupaya untuk mempelajari dan memahami kasus secara spesifik dan melakukan generalisasi terhadap kasus tersebut. Lokasi penelitian di Madrasah Ibtidaiyah Nahdlatul Wathan. Madrasah ini terletak di desa Tanak Beak, kecamatan Narmada, Kabupaten Lombok Barat. Subjek penelitian dalam penelitian ini adalah anak tuna laras dengan jumlah 5 anak. Pengumpulan data menggunakan observasi dan wawancara mendalam. Informan utama dalam penelitian ini adalah guru pendamping khusus, guru kelas dan kepala sekolah. Data disajikan dalam bentuk deskriptif. Data tentang kasus yang diamati dianalisis secara deskripsi terinci. ${ }^{20}$ Analisis data dilakukan pada saat pengumpulan data di lapangan. Tahapan analisis data dilakukan dengan membaca secara keseluruhan data yang diperoleh, melakukan pengelompokan, mengambil data inti sesuai dengan kebutuhan penelitian, penyajian data dan penarikan kesimpulan. Uji keabsahan data menggunakan teknik triangulasi informan. Teknik ini dilakukan dengan melakukan komparasi informasi yang didapatkan pada masing-masing informan.

\section{HASIL DAN PEMBAHASAN}

Pendidikan karakter terhadap anak tuna laras yang diterapkan di madrasah inklusi menggunakan pendekatan kelembutan. Metode ini diadopsi dari metode dakwah yang

${ }^{20}$ John W. Creswell, Educational Research, Planning, Conducting and Evaluating Quantitative and Qualitative Research, ed. by Matthew Buchholtz, Fourth (Boston, USA: Pearson, 2012. 
diterapkan oleh Nabi Muhammad SAW. Berdasarkan hasil wawancara dengan kepala madrasah inklusi penggunaan metode ini dilatarbelakangi oleh karakter anak tuna laras yang cenderung kasar dan tidak mau menerima nasihat. Kondisi semacam ini identik dengan keadaan orang-orang kafir yang tidak mau membuka hati untuk meneria dakwah nabi. Melalui pendekatan damai dan penuh dengan kelembutan akhirnya orang-orang kafir secara perlahan mau menerima ajaran nabi. Kunci keberhasilan dakwah nabi terletak pada penggunaan metode kelembutan ini. Hal inilah yang menginspirasi madrasah inklusi untuk menggunakan kelembutan hati dalam mendidik anak tuna laras. Metode ini diadopsi setelah beberapa kali menggunakan metode tidak membuahkan hasil. Salah satunya dengan menerapkan hukuman bagi setiap pelanggar aturan. Ketika anak tuna laras diberi hukuman justru membuat anak tuna laras menjadi lebih giat untuk melanggar. Bahkan mereka cenderung mencari perhatian guru dengan melakukan tindakan ekstrim. Kegagalan demi kegagalan terhadap metode yang diterapkan dalam membentuk karakter membuat madrasah harus berpikir keras untuk mencari jalan keluarnya. Hingga pada akhirnya metode yang dipilih adalah dengan pendekatan kelembutan sesuai yang dicontohkan oleh Rasulullah SAW.

Pembinaan karakter anak tuna laras dengan menggunakan metode kelembutan dilakukan secara persuasif. Tahapannya adalah identifikasi awal, penentuan jenis kelainan, assessment dan program pembelajaran individual. Pembinaan karakter dilakukan pada tahapan pembelajaran individual. Teknis yang dilakukan guru adalah dengan membimbing anak tuna laras di ruang sumber atau tempat lain yang merasa nyaman untuk memberikan bimbingan. Proses pembinaan karakter tidak hanya dilakukan di ruang sumber karena tidak semua anak tuna laras mau dibimbing pada ruang tersebut. Ruang sumber sebagi pusat pembinaan terkesan pemaksaan sehingga tidak jarang anak tuna laras justru berontak. Maka dari itu dalam proses pembinaan karakter lebih sering dilakukan secara kondisional. Guru memberikan keteladanan dan memberikan nasihat dengan penuh kasih sayang. Sikap tempramen dan keras dari anak tuna laras dilawan dengan kelembutan hati oleh para guru. Guru pembimbing dengan sabar mendidik dan membina karakter anak tuna laras. Terdapat lima anak tuna laras yang telah dilakukan pembinaan di madrasah inklusi. Berikut ini dapat disajikan deskripsi masing-masing subjek penelitian. 
Anak tuna laras yang pertama berinisial MZ berusia 12 tahun. Saat ini telah duduk di kelas VI. Karakter subjek pertama adalah keras kepala, tempramen, suka berbuat onar, suka berkata-kata kotor, memiliki hubungan sosial yang buruk dengan teman sebaya bahkan juga dengan guru, sangat jorok dan tidak mau mandi. Berdasarkan hasil wawancara dengan kepala sekolah subjek ini tidak mau mandi walaupun telah dipaksa. Hal ini dapat dipahami bahwa pembinaan karakter pada awalnya identik dengan pemaksaan. Pemberian hukuman merupakan salah satu cara yang digunakan sebelumnya. Mau tidak mau setiap anak harus patuh terhadap aturan yang ditetapkan madrasah tanpa mendengar keluh kesah anak tuna laras. Setelah dilakukan pembinaan karakter melalui pendekatan hati secara perlahan perilaku subjek pertama ini mulai berubah. Subjek pertama mulai mau mandi sendiri dan terlihat lebih bersih jika dibandingkan dengan sebelum dilakukan pembinaan. Perubahan perilakunya juga terlihat dari hubungan sosialnya yang lebih baik kepada guru dan teman sebayanya. Dalam hal akademik terjadi perubahan yang cukup signifikan yaitu terjadinya peningkatan partisipasi anak tuna laras dalam pembelajaran. Pada awalnya sering membolos tetapi setelah dilakukan pembinaan menjadi jarang membolos.

Anak tuna laras yang kedua berinisial AT berusia 13 tahun. Subjek kedua berada pada satu kelas dengan subjek pertama. Tidak jauh berbeda dengan subjek pertama, subjek kedua ini juga memiliki karakter yang keras. Perilakunya cenderung ekstrim, emosi tidak terkontrol, hubungan sosial tidak baik dan terhambat dalam kegiatan akademik. Sebelum dilakukan pembinaan dengan pendekatan hati subjek kedua tidak mengalami perubahan meskipun telah beberapa kali dilakukan terapi. Setelah dilakukan pembinaan dengan pendekatan hati terjadi perubahan yang cukup signifikan. Dari segi perilaku perubahan yang ditunjukkan adalah lebih taat aturan, seperti tidak datang terlambat dan menggunakan seragam sekolah yang sesuai. Sebelumnya subjek ini suka memakai seragam seenaknya, jika ditegur akan menjadi lebih marah dan mengeluarkan kata-kata kotor. Selain perilaku ekstrim yang sering dilakukan mulai berkurang. Berdasarkan hasil wawancara dengan guru pendamping khusus dapat diketahui bahwa subjek ini menjadi anak tuna laras karena kurang kasih sayang dari orang tua. Dengan kasih sayang dan kelembutan yang dilakukan oleh guru perubahan perilaku mulai terlihat. Dari sisi kontrol emosi subjek ini telah mengalami perbaikan. Subjek ini dapat mengontrol emosinya dengan baik. Tingkat partisipasi dalam proses belajar juga 
mengalami peningkatan. Hal ini ditunjukkan dengan berkurangnya angka tidak hadir tanpa keterangan yang sering dilakukannya.

Subjek ketiga berinisial MN yang berusia 11 tahun. Saat ini XY telah duduk di kelas V. Perilaku yang ditunjukkan oleh subjek ini sangat buruk sehingga dikucilkan oleh teman sekelasnya. Menurut penuturan salah satu guru subjek ini pernah memukul guru olah raga menggunakan sebuah kayu. Tidak hanya itu teman-teman sekelasnya juga sering mengalami tindakan kekerasan. Kondisi emosi yang tidak stabil membuat subjek ini mudah tersinggung. Terlebih lagi pembulian dan ejekan dari teman-temannya membuat karakternya semakin buruk. Telah beberapa kali dilakukan pembinaan tetapi tidak membuahkan hasil. Setelah dilakukan pembinaan dengan pendekatan hati secara perlahan perilaku liar subjek ini dapat dikendalikan. Tindakan berbahaya yang sering dilakukan kepada guru dan teman sebayanya sudah jarang dilakukan. Emosinya sudah mulai stabil. Hubungan sosial yang buruk dengan teman sebaya sudah mulai membaik. Begitu juga hubungan sosial dengan guru. Subjek ketiga lebih patuh jika mendapat nasihat dari guru. Kata-kata kotor yang sering diucapkan juga sudah jarang dilakukan. Kegiatan belajar juga telah dapat diikuti dengan baik. Namun demikian masih terdapat beberapa hal yang harus dilakukan pembianaan secara terus menerus. Berdasarkan hasil wawancara dengan guru pendamping khusus, subjek ini hanya mau menerima nasihat dari guru tertentu. Terdapat beberapa guru yang dianggapnya masih menjadi musuh, sehingga jika dinasihati tidak mau menurut. Selain itu subjek ini cenderung manja sehingga sangat menggantungkan diri pada salah seorang guru yang disayangi. Perilakunya cepat berubah jika aktivitasnya tidak dipandu oleh guru yang subjek ini inginkan.

Subjek keempat berinisial AM yang berusia 11 tahun. Saat ini telah duduk di kelas V. Karakteristik subjek keempat tidak berbeda jauh dengan subjek sebelumnya. Subjek keempat juga memiliki karakter yang tidak baik. Perilakunya cenderung kasar, susah diatur dan memiliki tingkat emosional yang tinggi. Selain itu subjek keempat juga memiliki hubungan yang buruk dengan teman sebayanya. Seringkali ia melakukan tindakan kasar kepada teman-temannya. Implikasinya adalah sering dikucilkan dan dijadikan bahan ejekan. Tidak mempuyai teman dan merasa diasingkan membuat anak ini semakin nakal. Sesekali ia datang ke sekolah hanya berbuat onar. Selepas itu ia pergi dan akan kembali masuk kelas beberapa hari berikutnya. Tindakan semacam ini menurut 
penuturan guru sering dilakukan. Nasihat demi nasihat yang diberikan atau bahkan hukuman tidak pernah membuatnya jera. Setelah dilakukan pendekatan persuasif dengan penuh kelembutan hati perilaku subjek keempat mulai berubah. Perilaku impulsif yang sering dilakukan semakin berkurang. Pada awalnya dia tidak dapat diam, selalu saja usil. Hal ini dikarenakan subjek keempat selain tuna laras juga hiperaktif. Kombinasi kedua gangguan ini membuat perilakunya condong kepada perilaku negatif. Namun setelah dilakukan pendekatan akhirny menjadi lebih tenang dan dapat mengendalikan perilakunya. Menurut keterangan dari salah satu guru penggunaan pendekatan hati memiliki efek positif terhadap kegiatan akademik. Tingkat partisipasi di dalam kelas juga meningkat. Pada awalnya tidak pernah memperhatikan guru, tidak mau mengerjakan pekerjaan rumah dan tidak mau belajar di dalam kelas. Setelah menggunakan pendekatan tersebut secara berkala permasalahan akademiknya mulai meningkat.

Subjek kelima berinisial ZM yang berusia 12 tahun. Perilaku tidak baik yang ditunjukkan oleh subjek kelima tidak hanya di lingkungan madrasah saja, tetapi juga terbawa dalam lingkungan sosialnya. Berkali-kali diberi hukuman oleh guru namun tidak mengalami perubahan. Selain itu kondisi emosional anak ini juga tidak stabil. Seringkali menunjukkan perilaku tantrum jika tidak dituruti kemauannya. Seperti halnya subjek keempat selain tuna laras juga hiperaktif. Anak ini cenderung tidak mau diam, selalu mengganggu temannya ketika belajar. Berdasarkan hasil wawancara dengan guru anak ini tidak pernah jika tidak membuat nangis teman setiap harinya. Tidak mau mengalah dan tidak pernah menghargai kepentingan orang lain. Selalu ada saja tindakan kekerasan yang dilakukan baik verbal maupun non verbal. Jika dinasihati dia akan melawan dan akan memusuhi orang yang memberi nasihat. Bahkan beberapa kali guru mendapat ancaman. Melawan guru adalah hal biasa yang dilakukan oleh anak tuna laras ini. Namun setelah dilakukan pendekatan dengan kelembutan perilaku tidak baik yang dilakukan mulai berubah secara bertahap. Hubungan sosial dengan teman sebaya mulai membaik. Para guru yang awalnya selalu dilawan sekarang sudah dipatuhi. Namun demikian masih ada beberapa perilaku yang masih melekat dan sulit dihilangkan yaitu sifat tantrumnya. Sifat tantrumnya masih sering kambuh. Beberapa kali anak tuna laras ini mengalami tantrum jika apa yang dikehendakinya tidak dituruti. Sifatnya akan cepat berubah jika apa yang diinginkan telah dipenuhi. Namun demikian siafat tantrumnya 
sudah jauh berkurang jika dibandingkan dengan sebelum pembinaan. Menurut penuturan guru anak ini kurang mendapat kasih sayang dari orang tuanya. Hal ini dikarenakan kedua orang tuanya bekerja sebagi TKI di luar negeri sehingga berakibat tidak baik kepada kondisi psikologisnya. Guru harus ekstra sabar dalam menghadapi setiap perilaku anak tuna laras. Para guru telah menyadari bahwa perilaku tidak baik yang dilakukan anak tuna laras bukan karena keinginan pribadinya tetapi karena gangguan psikologis yang dideritanya.

Berdasarkan paparan data di atas dapat dipahami bahwa penggunaan pendekatan hati yang dilakukan madrasah dalam membina karakter anak tuna laras telah membuahkan hasil. Walaupun masih terdapat beberapa anak tuna laras yang belum sembuh secara total tetapi setidaknya telah menunjukkan adanya perbaikan. Hal ini dapat dipahami bahwa pendidikan karakter membutuhkan pembiasaan. ${ }^{21}$ Artinya adalah perlu proses untuk membentuk karakter menjadi lebih baik. Terlebih lagi penanaman karakter terhadap anak berkebutuhan khusus membutuhkan proses yang lebih panjang. Internalisasi nilai-nilai karakter anak berkebutuhan khusus juga membutuhkan keteladanan, pembiasaan dan sedikit intervensi agar program pendidikan berjalan dengan baik. ${ }^{22} \mathrm{Hal}$ ini berlaku juga untuk anak tuna laras, karena anak tuna laras memang mengalami gangguan psikologis sehingga melakukan tindakan di luar kontrol. Membina karakter anak normal dengan anak yang mengalami gangguan tentulah berbeda.

Penggunaan pendekatan hati dalam membina karakter anak tuna laras di madrasah inklusi lebih efektif jika dibandingkan dengan metode lain yang pernah diterapkan. Sistem pendidikan dengan meneledani ajaran Rasulullah menjadi visi utama dalam menyelenggarakan program pendidikan anak berkebutuhan khusus di madrasah inklusi. Metode yang diterapkan di madrasah inklusi dalam membina karakter anak tuna laras mengadopsi sistem dakwah nabi. Sistem dakwah yang diambil adalah dakwah bil hikmah. Melalui metode ini seseorang yang menjadi sasaran dakwah secara suka rela mau mengikuti ajaran pendakwah tanpa ada konflik ${ }^{23}$. Metode ini dilakukan secara arif

\footnotetext{
${ }^{21}$ Muhammad Sobri and others, Pembentukan Karakter Disiplin Siswa Melalui Kultur Sekolah, Harmoni Sosial: Jurnal Pendidikan IPS, 6.1, 2019, hlm. 61-71 <https://doi.org/10.21831/hsjpi.v6i1.26912>.

22 Timothy Lintner, Using "Exceptional” Children's Literature to Promote Character Education in Elementary Social Studies Classrooms, The Social Studies, 102.5, 2011, hlm. 200-203 <https://doi.org/10.1080/00377996.2010.550955>.

${ }^{23}$ Nur Alhidayatillah, Urgensi Dakwah Bil Hikmah Pada Generasi Millenial, Idarotuna, 1.2 , 2019, hlm.33-66 <https://doi.org/10.24014/idarotuna.v1i2.7024>.
} 
dan bijaksana serta menggunakan pendekatan persuasif sehingga objek dakwah tidak merasa ada paksaan. Melalui adopsi sistem dakwah bil hikmah madrasah berharap agar anak tuna laras dapat merubah karakternya secara suka rela. Anak tuna laras dilakukan pendekatan khusus agar tidak merasa terpaksa. Melalui metode dakwah ini kondisi psikologis orang yang menjadi sasaran dakwah harus diperhatikan. ${ }^{24} \mathrm{Hal}$ ini dilakukan karena karakter anak tuna laras cenderung melawan jika dipaksa. Akibatnya karakter tidak berubah justru menambah konflik baru yang dapat merugikan madrasah dan anak tuna laras itu sendiri.

Metode dakwah bil hikmah yang diterapkan pada anak tuna laras adalah dengan melakukan pendekatan khusus. ${ }^{25}$ Masing-masing anak tuna laras dilakukan pendekatan yang berbeda. Ada yang dilakukan pendekatan melalui hobinya ada juga pendekatan melalui emotional argument, Argument based on credibility dan pendekatan psikologis. Melalui hobi yang dimiliki oleh anak tuna laras guru melakukan komunikasi persuasif dengan cara mengajak dan memberi motivasi kepada anak tuna laras untuk berperilaku baik. Anak tuna laras didukung untuk mengembangkan hobinya seperti olah raga atau seni. Mereka diberi pemahaman bahwa lebih baik melakukan hal-hal positif melalui olah raga atau seni karena dapat bermanfaat untuk dirinya dan juga membawa nama baik madrasah. Guru selalu mendukung hobi anak tuna laras dengan menyediakan fasilitas yang dibutuhkan termasuk juga dukungan dana untuk mengikuti perlombaan. Dengan cara ini anak tuna laras dapat melampiaskan dorongan psikologisnya ketika akan berperilaku tidak baik. Pendekatan persuasif kedua yang dilakukan adalah dengan metode emotional argument. Metode ini dilakukan dengan cara melakukan ajakan dengan memanfaatkan sisi emosional anak tuna laras. ${ }^{26}$ Ajakan dirangkai dengan katakata bijak atau humor untuk menarik perhatian anak tuna laras. Hal ini dilakukan karena seringkali ketika guru menggunakan cara emosional negatif ketika memberikan nasihat sehingga tidak mendapat respon yang baik dari anak tuna laras. Emosional negatif biasanya dilakukan guru dengan cara memarahi anak ketika anak tuna laras berbuat tidak

${ }^{24}$ Ulfatun Hasanah, Dakwah Bil-Hikmah: Membangun Etos Kerja Islami Dalam Masyarakat Priyayi Jawa ( Analisis Pegawai Pemerintahan Kelurahan Bangetayu Kulon, Kecamatan Genuk', AlI'lam; Jurnal Komunikasi Dan Penyiaran Islam, 1.2, 2018, hlm. 81-89 <https://doi.org/https://doi.org/10.31764/jail.v1i2.233>.

${ }^{25}$ Ricky Febrian, Dakwah Persuasif Terhadap Anak Berkebutuhan Khusus Di SLBN Baradatu Kabupaten Waykanan (Studi Upaya Meningkatkan Pemahaman Agama) Universitas Islam Negeri Raden Intan Lampung: 2019.

${ }^{26}$ Christine Clavien, Altruistic Emotional Motivation: An Argument in Favour of Psychological Altruism', 2012, hlm. 275-96 <https://doi.org/10.1007/978-94-007-1951-4_13>. 
baik. Cara ini cenderung tidak masuk dalam hati anak tuna laras dan justru akan menimbulkan respon negatif.

Metode ketiga yang diterapkan adalah argument based on credibility. ${ }^{27}$ Metode ini dilakukan dengan cara memberikan nasihat kepada anak tuna laras melalui seorang guru yang memiliki kharisma. Cara ini dilakukan karena anak tuna laras sering kali melawan nasihat guru dengan mengeluarkan argument untuk pembenaran perilakunya. Dengan memanfaatkan guru yang berkharisma anak tuna laras biasanya lebih patuh. Guru berkharisma tidak menasihati dengan cara menakuti tetapi dengan menggunakan pendekatan hati. Akan tetapi cara ini tidak dapat dilakukan oleh semua guru. Hanya guru tertentu saja yang dianggap memiliki kedekatan emosional dengan anak tuna laras. Metode yang terakhir adalah metode psikologis. Metode psikologis dilakukan dengan memperhatikan kondisi psikologis anak tuna laras. Anak tuna laras sering mengalami kesulitan dalam menyesuaikan diri (emosi), kurang "fokus", kontrol sosial yang kurang dan bertingkah laku menyimpang dari kondisi normal. ${ }^{28}$ Seorang guru dituntut untuk memahami bagaimana kondisi psikologis anak. Nasihat tidak akan masuk ke dalam hati anak tuna laras jika dia dinasihati dalam kondisi psikologis yang tidak stabil, misalnya ketika sedang marah besar atau ketika sedang bersedih. Anak tuna laras yang sedang marah besar harus ditenangkan terlebih dahulu sebelum diberi nasihat. Hal ini dilakukan karena dalam kondisi psikologis yang tidak stabil seseorang sulit menerima ajakan atau nasihat. Seseorang dalam level psikologis semacam ini hatinya sedang tertutup sehingga sulit dipengarui.

Inti dari berbagai macam pendekatan persuasif di atas adalah komunikasi persuasif antara guru dengan anak tuna laras. Komunikasi merupakan proses pengiriman pesan dari komunikator kepada komunikan. ${ }^{29}$ Komunikator dalam kasus ini adalah guru, sedangkan komunikannya adalah anak tuna laras. Pesan yang ingin disampaikan adalah pesan yang baik untuk membentuk karakter menjadi lebih baik. Sungguhpun pesannya baik jika disampaikan dengan cara yang kurang tepat maka hasilnya akan menjadi tidak

27 Chia-Ying Li, The Effects of Source Credibility and Argument Quality on Employees, Responses toward Information System Usage, Asia Pacific Management Review, 20.2, 2015, hlm. 56-64 <https://doi.org/10.1016/j.apmrv.2014.12.003>.

${ }^{28}$ Cindhi Dwi Permatasari, Ika Ratniarsih, and Sukarnen, Penerapan Konsep Representatif Intensif Pada Desain Ruang Fasilitas Edukasi Anak Tunalaras Di Surabaya, in Seminar Nasional Sains Dan Teknologi Terapan VI (Surabaya: Institut Teknologi Adhi Tama Surabaya, 2018, hlm. 477-84.

${ }^{29}$ Ahmad Zaenuri, Teknik Komunikasi Persuasif Dalam Pengajaran, JALIE: Journal of Applied Linguistics and Islamic Education, I.I, 2017, hlm. 41-67 <https://doi.org/-10.33754/jalie.v1i1.83>. 
baik. Penggunaan metode komunikasi yang tepat dapat memudahkan seseorang untuk memahami pesan yang disampaikan sehingga dapat merubah pola pikir dan perilaku yang diinginkan. Begitu pula dengan dakwah atau internalisasi nilai-nilai karakter terhadap anak tuna laras. Maka dari itu dalam proses komunikasi atau penyampaian pesan seorang guru tidak boleh berkata keras, marah-marah atau mencela anak tuna laras. Seorang guru harus bersikap lemah lembut dalam mendidik anak tuna laras meskipun anak tuna laras sering membuat jengkel dan bertidak semaunya.

Ajaran untuk memperlakukan orang lain dengan lemah telah diajarkan dalam Al Quran. Hal ini telah terdapat pada Quran Surat Thaha ayat 43-44:

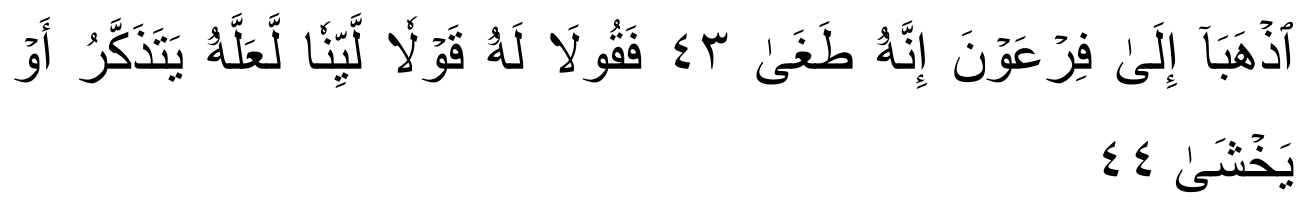

Artinya “43. Pergilah kamu berdua kepada Fir'aun, sesungguhnya dia telah melampaui batas. 44. Maka berbicaralah kamu berdua kepadanya dengan kata-kata yang lemah lembut, mudah-mudahan ia ingat atau takut".

Ayat di atas mengajarkan kepada setiap manusia untuk berperilaku santun dalam bertutur kata bahkan kepada musuh sekalipun. Terlebih lagi kepada anak tuna laras yang pada hakikatnya anak berebutuhan khusus yang membutuhkan pertolongan agar dapat keluar dari permasalahan psikologis yang dihadapi. Maka dari itu dalam memberikan nasihat hendaknya guru tetap menggunakan kata-kata yang baik. Ajaran untuk berlaku lemah lembut kepada orang lain juga tercantum di dalam Quran surat Ali Imran ayat 159:

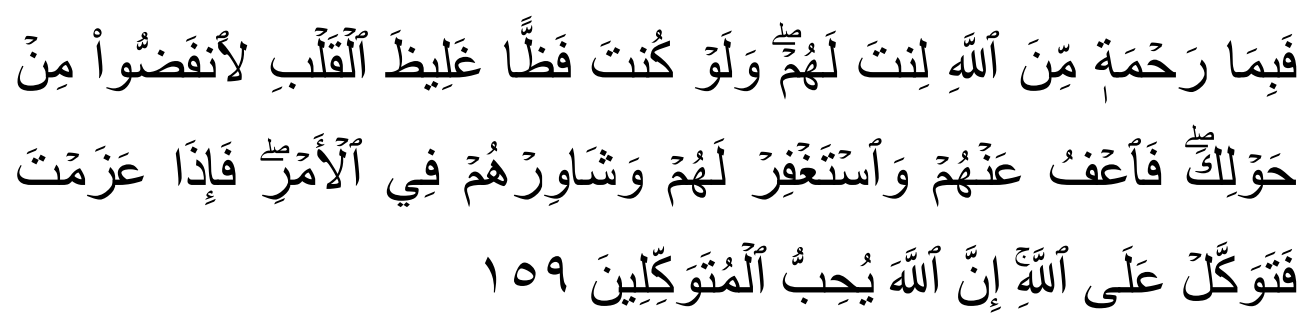

Artinya "Maka disebabkan rahmat dari Allah-lah kamu berlaku lemah lembut terhadap mereka. Sekiranya kamu bersikap keras lagi berhati kasar, tentulah mereka menjauhkan diri dari sekelilingmu. Karena itu maafkanlah mereka, mohonkanlah ampun bagi mereka, dan bermusyawaratlah dengan mereka dalam urusan itu. Kemudian apabila kamu telah membulatkan tekad, 
maka bertawakkallah kepada Allah. Sesungguhnya Allah menyukai orangorang yang bertawakkal kepada-Nya"

Surat Ali Imran ayat 159 di atas juga telah jelas bahwa manusia diajarkan untuk berbuat baik, lemah lembut, dan saling memaafkan. Bersikap kasar tidak akan menyelesaikan masalah justru akan menambah masalah baru. Cara yang lemah lembut ini telah dipraktikkan oleh Nabi ketika berdakwah, yaitu metode dakwah bil hikmah. Metode ini telah diadopsi oleh madrasah inklusi dalam mendidik karakter anak tuna laras. Model pendidikan karakter yang dikembangkan juga meneladani cara nabi ketika mendidik anak-anaknya. Bentuk pendidikan karakter yang dilakukan Nabi antara lain melalui teguran. ${ }^{30}$ Cara Nabi dalam menegur atau mengingatkan dilakukan secara lemah lembut. Nabi tidak pernah marah-marah atau berkata kasar apalagi melakukan kekerasan fisik ketika memberi nasihat. Nabi juga selalu memberikan perhatian penuh kepada anak-anaknya dalam mendidik. Setiap perilaku dan perkembangannya selalu diamati. Nabi juga tidak pernah lupa untuk mendoakan anak-anaknya. Bentuk pendidikan Nabi juga dilakukan melalui suri tauladan yang baik. Salah satu bentuk teladan yang dianjurkan oleh nabi adalah kejujuran. Maka dari itu guru harus menjadi role model bagi siswa-siswanya sehingga dapat menjadi contoh yang dapat ditiru perilakunya.

Pendidikan yang sesuai dengan ajaran Rasullah juga telah diterapkan di madrasah inklusi. Semua siswa dibiasakan untuk melakukan kegiatan religius. Para guru tidak pernah lupa untuk mendoakan keselamatan dan keberkahan ilmu yang diajarkan kepada setiap siswanya. Kegiatan rutin ini dilakukan melalui shalat duha berjamaah dan membaca shalawat secara bersama-sama. Internalisasi nilai-nilai religius di madrasah telah memberikan efek positif kepada para peserta didik. Anak-anak menjadi lebih tenang dan hati menjadi lembut sehingga mudah ketika diberi nasihat. Aura positif dari pembiasaan dan keteladanan dari seorang guru dapat menyentuh hati anak tuna laras. Hal ini dilakukan karena anak tuna laras pada hakikatnya tidak mau dipaksa tetapi juga diberi keteladanan dan pemberian solusi yang efektif. Anak-anak selalu diajarkan untuk menghargai perbedaan. Kemampuan anak untuk menghargai perbedaan merupakan salah

${ }^{30}$ Dwi Sukmalia Sayska, Implementasi Nilai Religius Dalam Pendidikan Karakter Berbasis Sunnah Rasullullah, Jurnal Manajemen Pendidikan Dan KeIslaman, 6.2, 2017, hlm. 1-13 $<$ http://jurnal.uinsu.ac.id/index.php/hijri/article/view/1135/892>. 
satu dasar dalam pendidikan karakter. ${ }^{31}$ Melalui cara ini diharapkan masing-masing anak tidak saling mengejek yang dapat menimbulkan permusuhan.

Pada beberapa kasus anak tuna laras tertentu guru harus melakukan komunikasi persuasif yang lebih ekstra. Bahkan untuk kasus anak tuna laras yang tidak mau mandi seorang guru rela membelikan perlengkapan mandi yang dibutuhkan anak tuna laras. Tidak hanya itu faktor terpenting dalam pembinaan ini adalah kesabaran guru dalam mendengar curhatan anak tuna laras. Melalui cara ini anak tuna laras merasa lebih dihargai sebagai manusia. Hal ini dilakukan mengingat anak tuna laras rata-rata berasal dari keluarga broken home atau berasal dari keluarga TKW. Anak tuna laras terkesan tidak terurus oleh keluarganya. Terlebih lagi jika pengasuhan hanya dipegang oleh nenek. Usia yang sudah lanjut tidak memungkinkan untuk memberikan perhatian dan bimbingan secara maksimal. Kondisi tersebut secara tidak langsung dapat berpengaruh terhadap pembentukan karakter seorang anak. Maka dari itu setiap guru di madrasah inklusi dituntut untuk memiliki kepekaan dalam memahami kesulitan yang dihadapi anak-anak tuna laras. Terlebih lagi selama ini anak tuna laras hanya sebagai bahan bulian teman sebaya dan selalu dianggap sebagai anak nakal.

\section{SIMPULAN}

Berdasarkan hasil penelitian dapat disimpulkan penggunaan metode dakwah bil hikmah sebagai pendekatan dalam membina karakter anak tuna laras telah berhasil. Indikator keberhasilan dari penggunaan metode dakwah bil hikmah antara lain: perilaku anak tuna laras semakin membaik, emosi dapat terkontrol hubungan sosial dengan teman saya dan guru juga membaik serta meningkatnya partisipasi anak tuna laras dalam kegiatan pembelajaran.

${ }^{31}$ Arif Widodo and others, Tolerance Education Among Religious Community Based on the Local Wisdom Values in Primary Schools, in Proceedings of the 1st Annual Conference on Education and Social Sciences (ACCESS), Paris, France: Atlantis Press, 2020, CDLXV, hlm. 327-30 <https://doi.org/10.2991/assehr.k.200827.082>. 


\section{DAFTAR PUSTAKA}

A.V, Exwan, Akhmad Rivai, Riska Putri, dan Niwang Tungung, Program "Lombok Rawit" Sebagai Sarana Terapi Bagi Anak Tunalaras, Pelita: Jurnal Penelitian Mahasiswa $U N Y, 9.02,2014$.

Abdullah, Nandiyah, Mengenal Anak Berkebutuhan Khusus, Magistra, XXV.86, 2013.

Alhidayatillah, Nur, Urgensi Dakwah Bil Hikmah Pada Generasi Millenial, Idarotuna, 1.2,<https://doi.org/10.24014/idarotuna.v1i2.7024>, 2019

Bihastuti, Endhita Januar, Penerapan Healing Environment Pada Perancangan Sekolah Dasar Luar Biasa Bagian Tunalaras, ARSITEKTURA, 15.2,<https://doi.org/10.20961/arst.v15i2.12596>, 2017

Burhaein, Erik, Aktivitas Permainan Tradisional Berbasis Neurosainslearning Sebagai Pendidikan Karakter Bagi Anak Tunalaras, Jurnal SPORTIF : Jurnal Penelitian Pembelajaran, 3.1,<https://doi.org/10.29407/js_unpgri.v3i1.580>, 2017

Clavien, Christine, Altruistic Emotional Motivation: An Argument in Favour of Psychological Altruism,<https://doi.org/10.1007/978-94-007-1951-4_13>, 2012

Creswell, John W., Educational Research, Planning, Conducting and Evaluating Quantitative and Qualitative Research, ed. by Matthew Buchholtz, Fourth, Boston, USA: Pearson, 2012.

Dermawan, Oki, Strategi Pembelajaran Bagi Anak Berkebutuhan Khusus Di SLB, Psympathic: Jurnal Ilmiah <https://doi.org/10.15575/psy.v6i2.2206>, 2018

Febrian, Ricky, Dakwah Persuasif Terhadap Anak Berkebutuhan Khusus Di SLBN Baradatu Kabupaten Waykanan (Studi Upaya Meningkatkan Pemahaman Agama), Universitas Islam Negeri Raden Intan Lampung, 2019

Hakim, Arif Rohman, Memuliakan Anak Berkebutuhan Khusus Melalui Pendidikan Jasmani Adaptif, Jurnal Ilmiah Penjas, 3.1,<http://ejournal.utp.ac.id/index.php/JIP/article/view/539>, 2017

Hasanah, Ulfatun, Dakwah Bil-Hikmah:Membangun Etos Kerja Islami Dalam Masyarakat Priyayi Jawa (Analisis Pegawai Pemerintahan Kelurahan Bangetayu Kulon , Kecamatan Genuk ), Al-I'lam; Jurnal Komunikasi Dan Penyiaran Islam, 1.2,<https://doi.org/https://doi.org/10.31764/jail.v1i2.233>, 2018

Husna, Difaul, Internalisasi Nilai-Nilai Sosial Religius Bagi Anak Tunalaras Di SLB E Prayuwana Yogyakarta, Jurnal Tarbiyatuna, 11.1, <https://doi.org/10.31603/tarbiyatuna.v11i1.3044>, 2020. 
Indriyati, Aas, Peningkatan Pengendalian Diri Pada Anak Tuna Laras Dengan Menggunakan Pendekatan Teknik Konseling Behavioral Di Smkn 3 Bandung, Jurnal Penelitian Pendidikan, 17.2, <https://ejournal.upi.edu/index.php/JER/article/view/8245>, 2017.

Jauhari, Ana Rafikayati dan Muhammad Nurrohman, Keterlibatan Orangtua Dalam Penanganan Anak Berkebutuhan Khusus, Belantika Pendidikan, 2.1, 2018.

Kusmawati, Ati, Cholichul Hadi, dan M.G. Bagus Ani Putra, Terapi Al-Qur'an Pada Siswa Tunalaras, JSSH (Jurnal Sains Sosial Dan Humaniora), 2.1,<https://doi.org/10.30595/jssh.v2i1.2199>, 2018

Li, Chia-Ying, The Effects of Source Credibility and Argument Quality on Employees' Responses toward Information System Usage, Asia Pacific Management Review, 20.2,<https://doi.org/10.1016/j.apmrv.2014.12.003>, 2015

Lintner, Timothy, Using "Exceptional” Children's Literature to Promote Character Education in Elementary Social Studies Classrooms, The Social Studies, 102.5, <https://doi.org/10.1080/00377996.2010.550955>, 2011.

Mahabati, Aini, Pola Perilaku Bermasalah Dan Rancangan Intervensi Pada Anak Tunalaras Tipe Gangguan Perilaku (Conduct Disorder) Berdasarkan Fungsctional Behavior Assesment, Dinamika Pendidikan, 21.01, <https://journal.uny.ac.id/index.php/dinamika-pendidikan/article/view/2851>,2014

Mahabbati, Aini, Pendidikan Inklusif Untuk Anak Dengan Gangguan Emosi Dan Perilaku (Tunalaras), Jurnal Pendidikan Khusus, 7.2,<https://doi.org/https://doi.org/10.21831/jpk.v7i2.778>, 2010.

Nisa, Khairun, Sambira Mambela, dan Lutfi Isni Badiah, Karakteristik Dan Kebutuhan Pembelajaran Anak Berkebutuhan Khusus Dan Anak Berbakat, Abadimas Buana, 2.1, 2018 .

Nurhansari, Luxvina, Identifikasi Perilaku Anak Tunalaras ( Anak Agresif ) Di Sekolah Inklusi Siswa Kelas I SD N Bangunrejo 2 Yogyakarta, Jurnal Pendidikan Guru Sekolah Dasar, 29.7, 2018.

Padila, Setiawati, Iin Inayah, Henny Suzana Mediani, and Chatarina Suryaningsih, Emosi Dan Hubungan Antar Sebaya Pada Anak Tunalaras Usia Sekolah Antara Terapi Musik Klasik (Mozart) Dan Murrotal (Surah Ar-Rahman), Jurnal Keperwatan Silampari, 3.2,<https://doi.org/10.31539/jks.v3i2.1276>, 2020.

Permatasari, Cindhi Dwi, Ika Ratniarsih, dan Sukarnen, Penerapan Konsep Representatif Intensif Pada Desain Ruang Fasilitas Edukasi Anak Tunalaras Di Surabaya', in Seminar Nasional Sains Dan Teknologi Terapan VI, Surabaya: Institut Teknologi Adhi Tama Surabaya, 2018. 
Sayska, Dwi Sukmalia, Implementasi Nilai Religius Dalam Pendidikan Karakter Berbasis Sunnah Rasullullah, Jurnal Manajemen Pendidikan Dan KeIslaman, 6.2,<http://jurnal.uinsu.ac.id/index.php/hijri/article/view/1135/892>, 2017

Sobri, Muhammad, Nursaptini Nursaptini, Arif Widodo, and Deni Sutisna, Pembentukan Karakter Disiplin Siswa Melalui Kultur Sekolah, Harmoni Sosial: Jurnal Pendidikan IPS, 6.1, <https://doi.org/10.21831/hsjpi.v6i1.26912>, 2019.

Syamsi, Ibnu, Pelaksanaan Evaluasi Asesmen Akademik Siswa Tunalaras Di Slb-E Prayuwana, Jpk: Jurnal Pendidikan Khusus, 12.1, <https://doi.org/10.21831/jpk.v12i1.12837>, 2017.

Utami, Destri Wahyu, Mohammad Anwar, dan Hermawan Hermawan, Pengaruh Penggunaan Model Pembelajaran Assure Terhadap Peningkatan Prestasi Belajar IPA Anak Tunalaras Kelas IV Di SLB E Bhina Putera Surakarta Tahun Ajaran 2017/2018, JPI (Jurnal Pendidikan Inklusi), 2.1, <https://doi.org/10.26740/inklusi.v2n1.p5-14>, 2018.

Vuorinen, Kaisa, Anne Erikivi, dan Lotta Uusitalo-Malmivaara, A Character Strength Intervention in 11 Inclusive Finnish Classrooms to Promote Social Participation of Students with Special Educational Needs, Journal of Research in Special Educational Needs, 19.1,<https://doi.org/10.1111/1471-3802.12423>, 2019.

Widodo, Arif, Mohammad Archi Maulyda, Asri Fauzi, Deni Sutisna, Nursaptini Nursaptini, dan Umar Umar, Tolerance Education Among Religious Community Based on the Local Wisdom Values in Primary Schools, in Proceedings of the 1st Annual Conference on Education and Social Sciences (ACCESS 2019) Paris, France: Atlantis Press, CDLXV, 32<https://doi.org/10.2991/assehr.k.200827.082>, 2020.

Yarfin, La Ode, dan Suyadi, Pendidikan Akhlak Pada Anak Tunalaras Di Sekolah Luar Biasa Prayuwana Yogyakarta, Jurnal Pendidikan Islam, 11.1, 2020

Zaenuri, Ahmad, Teknik Komunikasi Persuasif Dalam Pengajaran, JALIE: Journal of Applied Linguistics and Islamic Education, I.I, <https://doi.org/10.33754/jalie.v1i1.83>, 2017 